\title{
Three New Oleanane-Type Triterpenoidal Glycosides from Impatiens balsamina and Their Biological Activity
}

\author{
Tae Hyun Lee ${ }^{1}$, Won Se Suh ${ }^{1}$, Lalita Subedi ${ }^{2,3}$, Sun Yeou Kim ${ }^{2,3}$, Sang Un Choi ${ }^{4}$, \\ Kang Ro Lee ${ }^{1}$ and Chung Sub Kim ${ }^{1} *$ (D) \\ 1 School of Pharmacy, Sungkyunkwan University, Suwon 16419, Korea; thlee16@skku.edu (T.H.L.); \\ wonse528@gmail.com (W.S.S.); krlee@skku.edu (K.R.L.) \\ 2 Gachon Institute of Pharmaceutical Science, Gachon University, Incheon 21936, Korea; \\ subedilali@gmail.com (L.S.); sunnykim@gachon.ac.kr (S.Y.K.) \\ 3 College of Pharmacy, Gachon University, Hambakmoero, Yeonsu-gu, Incheon 21936, Korea \\ 4 Korea Research Institute of Chemical Technology, Daejeon 34114, Korea; suchoi@krict.re.kr \\ * Correspondence: chungsub.kim@skku.edu; Tel.: +82-31-290-7727
}

Received: 22 July 2020; Accepted: 19 August 2020; Published: 24 August 2020

check for updates

\begin{abstract}
Three new oleanane-type triterpenoidal glycosides, imbalosides A-C (1-3), were isolated from the white flowers of Impatiens balsamina. The structures of these phytochemical constituents (1-3) were elucidated through 1D and 2D Nuclear Magnetic Resonance (NMR) and Mass Spectrometry (MS) data analyses followed by chemical methods. All the characterized compounds (1-3) were evaluated for their antiproliferative activity against four human tumor cell lines (A549, SK-OV-3, SK-MEL-2, and BT549) and their anti-neuroinflammatory activity on the basis of inhibition levels of nitric oxide (NO) in the lipopolysaccharide (LPS)-stimulated murine microglia BV-2 cell lines.
\end{abstract}

Keywords: Impatiens balsamina; balsaminaceae; triterpenoidal glycosides; cytotoxicity; anti-neuroinflammation

\section{Introduction}

Impatiens balsamina L., known as garden balsam or rose balsam, is an annual plant belonging to the family Balsaminaceae and is widely distributed in Korea, Japan, and mainland China. Diverse parts of I. balsamina, including flowers, stems, and leaves, have long been used as traditional medicines to treat various diseases. The flowers of I. balsamina have been used as remedies for lumbago, burns, and scalds [1], whereas its aerial parts have been used to treat articular rheumatism, abscesses, and tumors [2]. In the previous research on this plant, 1,4-naphthoquinone derivatives showed a variety of pharmacological effects such as antitumor, anti-inflammatory, and hepatoprotective activities [3-5].

As part of the continuing studies to identify the bioactive constituents from Korean medicinal plants [6-11], we previously conducted a phytochemical investigation on the MeOH extract of the white flowers of I. balsamina, which led to the isolation and characterization of phenolic compounds including mono- and biflavonoids with cytotoxic, anti-inflammatory, and neuroprotective activities [12,13]. In order to discover bioactive molecules in other structural classes from this plant, we further investigated its EtOAc-soluble layer and identified three new oleanane-type triterpenoidal glycosides (1-3) (Figure 1). The chemical structures of the new compounds (1-3) were established on the basis of spectroscopic (1D and 2D NMR) and spectrometric [High Resolution Fast Atom Bombardment MS (HRFABMS)] analyses as well as chemical methods. The isolates (1-3) were tested for their cytotoxicity against four human tumor cell lines and anti-neuroinflammatory activity using lipopolysaccharide (LPS)-stimulated murine microglia BV-2 cell lines. 


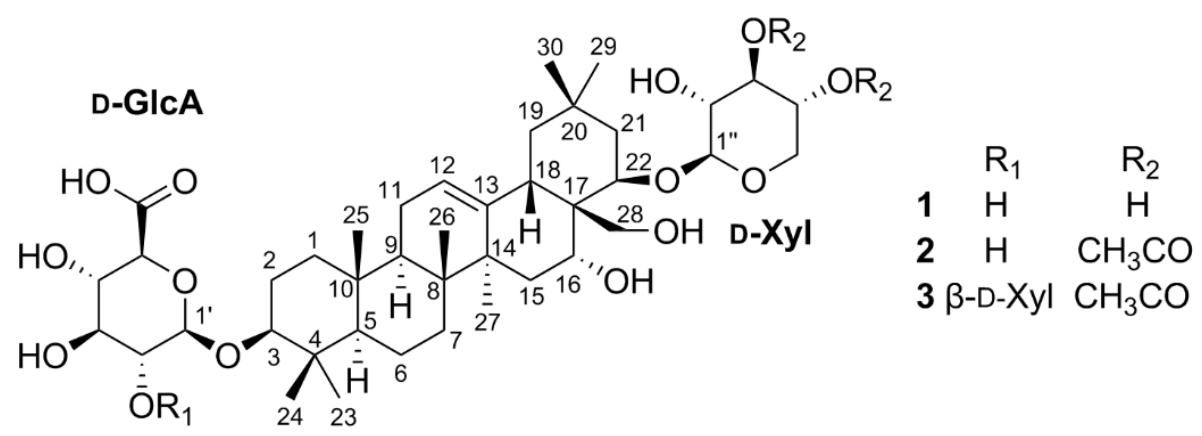

Figure 1. Chemical structures of compounds 1-3.

\section{Results and Discussion}

\subsection{Structure Elucidation}

Imbaloside A (1) was isolated as a colorless gum. The molecular formula of $\mathbf{1}$ was determined as $\mathrm{C}_{41} \mathrm{H}_{66} \mathrm{O}_{14}$ based on the $[\mathrm{M}-\mathrm{H}]^{-}$ion peak at $\mathrm{m} / \mathrm{z} 781.4368$ (calcd for $\mathrm{C}_{41} \mathrm{H}_{65} \mathrm{O}_{14}{ }^{-}, 781.4380$, error $=1.5 \mathrm{ppm}$ ) from the HRFABMS analysis. The ${ }^{1} \mathrm{H}$ NMR spectrum of $\mathbf{1}$ showed a broad singlet at $\delta_{\mathrm{H}} 5.30$ for an olefinic proton, overlapped signals from $\delta_{\mathrm{H}} 3.20$ to 4.38 for oxygenated methine/methylene protons, seven singlets at $\delta_{\mathrm{H}} 1.40,1.09,1.05,1.00,0.97,0.93$, and 0.88 for methyl protons, and the others in the region from $\delta_{\mathrm{H}} 2.28$ to 0.82 . Among a total of 41 carbons present in this molecule, 40 resonances were observed in the ${ }^{13} \mathrm{C}$ NMR spectrum of $\mathbf{1}$, including 30 peaks for typical oleanane-type triterpenoids [14-18] with two olefinic carbons at $\delta_{C} 144.6$ and 124.2 and four oxygenated carbons at $\delta_{C} 91.1,78.8,70.4$, and 65.8 , and ten peaks for $\beta$-glucuronic acid $\left(\delta_{C} 106.9,75.6,78.1,73.8\right.$, and 76.8$)$ and $\beta$-xylopyranose $\left(\delta_{C} 102.8,74.5,77.0,71.2\right.$ and 66.5). These ${ }^{1} \mathrm{H}$ and ${ }^{13} \mathrm{C}$ NMR data implied that 1 is an oleanane-type triterpenoidal glycoside with two sugar moieties, and its core structure including the location of a double bond and four oxygenated carbons was established through analysis of the Distortionless Enhancement by Polarization Transfer (DEPT), correlation spectroscopy (COSY), Heteronuclear Single Quantum Correlation (HSQC), and Heteronuclear Multiple Bond Correlation (HMBC) spectra (Figure 2, Supplementary Materials).
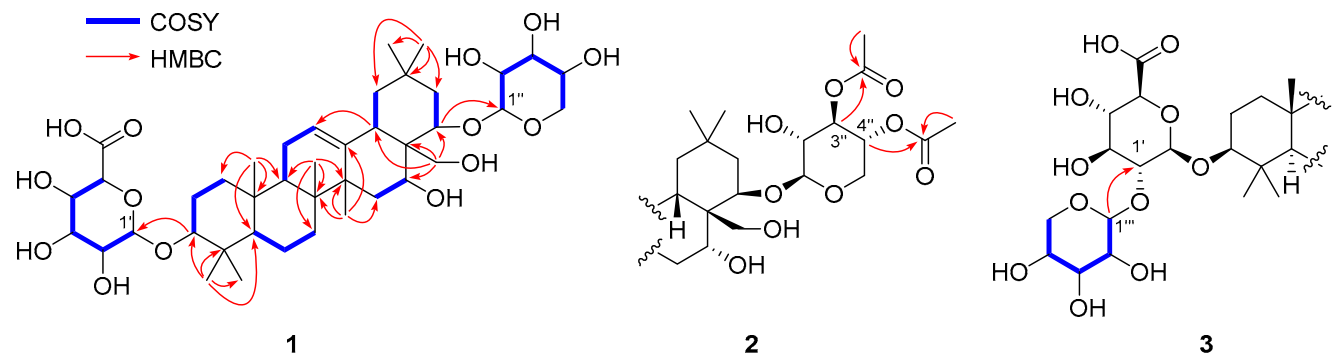

Figure 2. Key COSY (blue bold) and HMBC (red arrows) correlations of 1-3.

The $\beta$-configurations of the two anomeric carbons on the glucuronic acid and xylopyranose were assigned by the relatively large ${ }^{3} J$ coupling constants $(7.1 \mathrm{~Hz})$ between $\mathrm{H}-1$ and $\mathrm{H}-2$ of both sugars. These two sugar units were confirmed to be connected at C-3 (glucuronic acid) and C-22 (xylopyranose) by observing HMBC cross-peaks of $\mathrm{H}-3 / \mathrm{C}-\mathrm{1}^{\prime}$ and $\mathrm{H}-22 / \mathrm{C}-\mathrm{1}^{\prime \prime}$ (Figure 2). The relative configuration at C-3 was confirmed by the strong nuclear Overhauser effect (NOE) correlation of $\mathrm{H}-3$ with $\mathrm{H}-5$ along with the mild correlation of $\mathrm{H}-3$ with $\mathrm{H}-1$ ax (Figure $3 \mathrm{~A}$ ). The $\alpha$-orientation of the hydroxyl group at C-16 was verified by the strong NOE spectroscopy (NOESY) cross-peaks of H-16 with both H-15a and H-15b (Figure 3) and the relatively small coupling constant, 3.4 Hz, between H-16 and both $\mathrm{H}-15 \mathrm{a}$ and $\mathrm{H}-15 \mathrm{~b}$, indicating that $\mathrm{H}-16$ should be in equatorial position rather than axial position. This initial assignment of $\alpha-\mathrm{OH}$ at $\mathrm{C}-16$ was supported by observing a similar NMR chemical shift pattern around C-16 of camelliagenone (e.g., $\delta_{\mathrm{H}-15} 2.02$ and 1.42 for camelliagenone and $\delta_{\mathrm{H}-15}$ 
2.01 and 1.43 for $\mathbf{1}$ ) and the coupling constant (broad singlet at C-16 for camelliagenone and broad triplet with the small coupling constant $3.4 \mathrm{~Hz}$ for 1 ), which possess the same $\alpha$-orientation of the hydroxyl group at $\mathrm{C}-16$ [19]. The $\beta$-configuration of the alkoxy group at $\mathrm{C}-22$ was assigned by NOESY cross-peak of H-22 with H-19ax (Figure 3A) and coupling constant analysis (Figure 3B,C); the Newman projections of two possible 22-epimers suggested that both $\mathrm{H}-22 / \mathrm{H}-21$ eq and $\mathrm{H}-22 / \mathrm{H}-21$ ax are gauche in the $\beta$-OXyl epimer, whereas $\mathrm{H}-22 / \mathrm{H}-21 \mathrm{ax}$ is anti and $\mathrm{H}-22 / 21 \mathrm{eq}$ is gauche in the $\alpha$-OXyl epimer (Figure 3C). Generally, the coupling constant of two protons in anti (or axial-axial) orientation in cyclohexane is over $9-10 \mathrm{~Hz}$, which excluded the possibility of an $\alpha$-OXyl epimer for $\mathbf{1}$ since the observed coupling constants between H-22 and H-21ax,eq were both smaller than $8 \mathrm{~Hz}(7.6$ and $3.9 \mathrm{~Hz}$, respectively). In fact, camelliagenone has an $\alpha-\mathrm{OH}$ at $\mathrm{C}-22$ and the coupling constant between $\mathrm{H}-22$ and $\mathrm{H}-21 \alpha$ was $12.0 \mathrm{~Hz}$ [19]. The hydroxymethyl group at C-28 was confirmed as $\beta$-form by the NOE correlations of $\mathrm{H}-28 \mathrm{a}$ with $\mathrm{H}-18$ and $\mathrm{H}-28 \mathrm{~b}$ with $\mathrm{H}-15$ and $\mathrm{H}-26$ (Figure $3 \mathrm{~A}$ ). The absolute configurations of the glucuronic acid and xylopyranose were assigned as D-form by comparing retention times of their chiral derivatives with those of authentic samples [20]. Thus, the structure of $\mathbf{1}$ was defined as 3-O- $\beta$-D-glucuronyl-3 $\beta, 16 \alpha, 22 \beta, 28$-tetrahydroxyolean-12-ene-22-O- $\beta$-D-xylopyranoside.
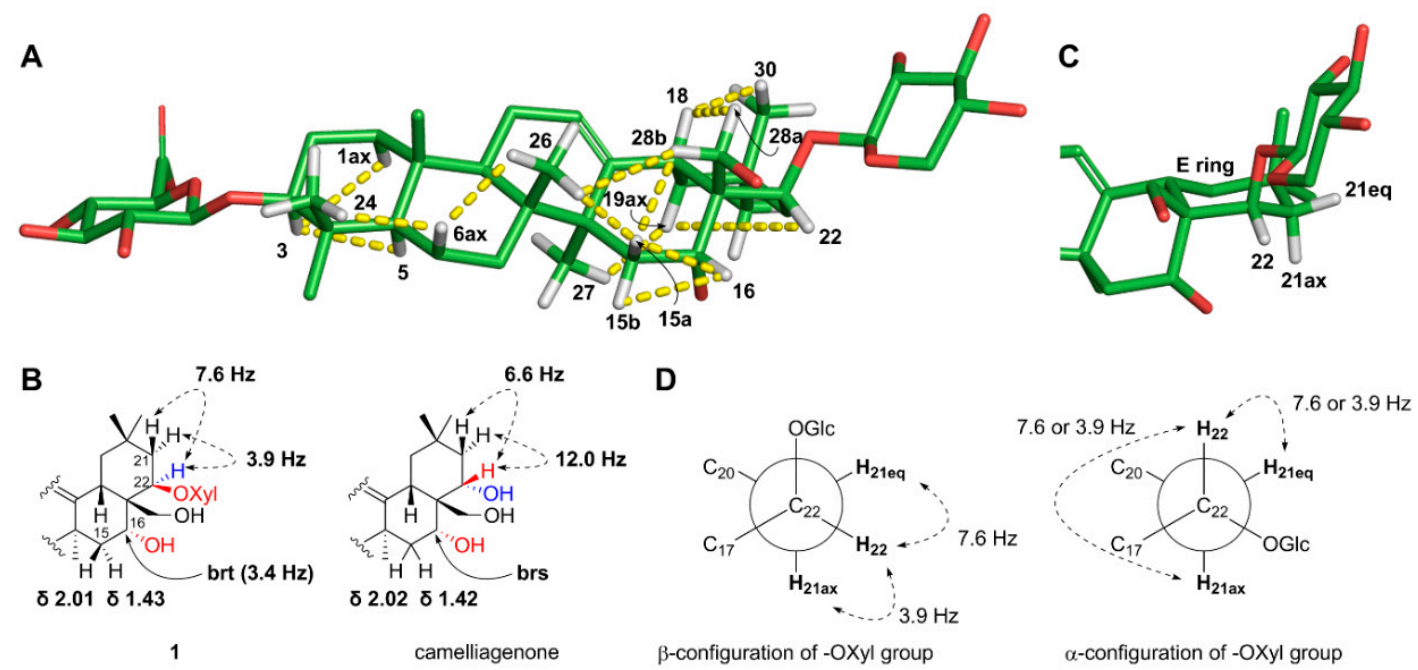

Figure 3. Stereochemical analysis of 1. (A) Key NOESY (yellow dashed) correlations of $\mathbf{1}$. The geometry of the 3D structure was minimized at the MMFF force field. Some protons were removed for a clearer presentation. (B) Comparison of selected chemical shifts and coupling constants of $\mathbf{1}$ and camelliagenone, which possesses the same $\alpha-\mathrm{OH}$ at $\mathrm{C}-16$ and the opposite $\alpha-\mathrm{OH}$ at $\mathrm{C}-22$ to those of $\mathbf{1}$. (C) Zoomed-in view around the E ring in 1. (D) Newman projections from C-22 to C-21 for the two possible 22-epimers and the observed coupling constants between H-22 and H-21eq,ax.

Imbaloside B (2) was obtained as a colorless gum, and its molecular formula was determined as $\mathrm{C}_{45} \mathrm{H}_{70} \mathrm{O}_{16}$ from the deprotonated HRFABMS ion peak at $m / z 865.4580$ (calcd for $\mathrm{C}_{45} \mathrm{H}_{69} \mathrm{O}_{16}{ }^{-}, 865.4591$, error $=1.3 \mathrm{ppm}$ ). The ${ }^{1} \mathrm{H}$ and ${ }^{13} \mathrm{C}$ NMR data were quite similar to those of compound $\mathbf{1}$ (Table 1 ), suggesting that compound $\mathbf{2}$ possesses the same core structure as compound $\mathbf{1}$, but apparent differences existed at the $\beta$-D-xylopyranose moiety in terms of the presence of two acetoxy groups $\left(\delta_{\mathrm{H}} 2.08\right.$ and $2.02 ; \delta_{C} 172.2,171.8,21.0$ and 20.7) (Table 1 ). The connectivity of the two acetoxy groups were verified on the basis of the HMBC cross-peaks from H-3" $\left(\delta_{\mathrm{H}} 5.09\right)$ to OAc- $3^{\prime \prime}\left(\delta_{\mathrm{C}} 172.2\right)$ and H-4" $\left(\delta_{\mathrm{H}} 4.87\right)$ to OAc- $4 "\left(\delta_{C} 171.8\right)$, respectively (Figure 2). According to the similar ${ }^{1} \mathrm{H}$ and ${ }^{13} \mathrm{C}$ NMR data and NOESY correlations to those of compound $\mathbf{1}$, the relative configuration of compound 2 was confirmed to be identical with that of $\mathbf{1}$. Thus, the chemical structure of 2 was assigned as 3-O- $\beta$-D-glucuronyl-3 $\beta, 16 \alpha, 22 \beta, 28$ -tetrahydroxyolean-12-ene-22-O-(3,4-O-diacetyl)- $\beta$-D-xylopyranoside. 
Table 1. ${ }^{1} \mathrm{H}$ [ppm, mult., $(J$ in $\left.\mathrm{Hz})\right]$ and ${ }^{13} \mathrm{C}$ NMR data of compounds $1-3$ in methanol- $d_{4}$.

\begin{tabular}{|c|c|c|c|c|c|c|}
\hline \multirow{2}{*}{ Position } & \multicolumn{2}{|r|}{1} & \multicolumn{2}{|r|}{2} & \multicolumn{2}{|r|}{3} \\
\hline & $\delta_{\mathrm{C}}$ & $\delta_{\mathrm{H}}$ & $\delta_{\mathrm{C}}$ & $\delta_{\mathrm{H}}$ & $\delta_{\mathrm{C}}$ & $\delta_{\mathrm{H}}$ \\
\hline $1 \mathrm{ax}$ & 40.2 & 1.65, overlap & 40.2 & 1.65 , overlap & 40.3 & 1.64 , overlap \\
\hline 1eq & & 1.01 , overlap & & 1.03 , overlap & & 1.02 , overlap \\
\hline $2 a x$ & 27.1 & 1.72 , overlap & 27.1 & 1.73, overlap & 27.2 & 1.73 , overlap \\
\hline 2eq & & 1.97 , overlap & & 2.00 , overlap & & 2.02, overlap \\
\hline 3 & 91.1 & 3.21 , overlap & 91.1 & 3.22 , overlap & 91.0 & 3.21 , overlap \\
\hline 4 & 40.4 & & 40.4 & & 40.5 & \\
\hline 5 & 57.3 & $0.82, \mathrm{~d}(11.6)$ & 57.3 & $0.82, \mathrm{~d}(11.6)$ & 57.3 & $0.80, \mathrm{~d}(11.5)$ \\
\hline $6 a x$ & 19.5 & 1.44 , overlap & 19.5 & 1.46 , overlap & 19.5 & 1.44 , overlap \\
\hline 6 eq & & 1.61 , overlap & & 1.61 , overlap & & 1.61 , overlap \\
\hline $7 a^{1}$ & 34.4 & 1.64 , overlap & 34.4 & 1.63, overlap & 34.4 & 1.63 , overlap \\
\hline $7 \mathrm{~b}$ & & 1.43 , overlap & & 1.42 , overlap & & 1.43, overlap \\
\hline 8 & 41.0 & & 41.0 & & 41.0 & \\
\hline 9 & 48.3 & 1.66, overlap & 48.3 & 1.67 , overlap & 48.3 & 1.66 , overlap \\
\hline 10 & 38.0 & & 38.0 & & 37.9 & \\
\hline 11 & 24.7 & 1.91 , overlap & 24.7 & 1.92 , overlap & 24.7 & 1.92 , overlap \\
\hline 12 & 124.2 & 5.30, brs & 124.2 & 5.30, brt (3.7) & 124.2 & 5.30, brt (3.7) \\
\hline 13 & 144.6 & & 144.6 & & 144.6 & \\
\hline 14 & 42.7 & & 42.7 & & 42.7 & \\
\hline $15 a x$ & 34.5 & 2.01, brd (13.5) & 34.6 & 2.02 , overlap & 34.6 & 2.04 , overlap \\
\hline $15 \mathrm{eq}$ & & 1.43, overlap & & 1.43 , overlap & & 1.44 , overlap \\
\hline $16^{1}$ & 70.4 & 4.25, brt $(3.4)$ & 70.5 & 4.24, brt $(3.5)$ & 70.5 & $4.23, \operatorname{brt}(3.4)$ \\
\hline 17 & 45.6 & & 45.6 & & 45.6 & \\
\hline 18 & 42.8 & 2.06, brd (13.0) & 42.8 & $2.10, \mathrm{~d}(13.2)$ & 42.8 & $2.10, \mathrm{~d}(13.1)$ \\
\hline $19 a x$ & 48.2 & $2.28, \mathrm{t}(13.4)$ & 48.2 & $2.29, \mathrm{t}(13.5)$ & 48.2 & $2.29, \mathrm{t}(13.4)$ \\
\hline $19 \mathrm{eq}$ & & 1.00 , overlap & & 1.00 , overlap & & 1.01 , overlap \\
\hline 20 & 31.1 & & 31.1 & & 31.1 & \\
\hline $21 \mathrm{ax}$ & 40.2 & $1.74, \mathrm{dd}(13.6,3.4)$ & 40.4 & $1.78, \mathrm{dd}(13.7,3.9)$ & 40.4 & $1.78, \mathrm{dd}(13.7,3.9)$ \\
\hline $21 \mathrm{eq}$ & & 1.65 , overlap & & 1.69, overlap & & 1.69, overlap \\
\hline 22 & 78.8 & $4.28, \mathrm{dd}(7.6,3.9)$ & 78.8 & $4.28, \mathrm{dd}(7.0,3.9)$ & 79.8 & $4.28, \mathrm{dd}(7.0,3.9)$ \\
\hline 23 & 28.7 & $1.09, \mathrm{~s}$ & 28.7 & $1.09, \mathrm{~s}$ & 28.4 & $1.09, \mathrm{~s}$ \\
\hline 24 & 17.2 & $0.88, \mathrm{~s}$ & 17.2 & $0.89, \mathrm{~s}$ & 16.8 & $0.88, \mathrm{~s}$ \\
\hline 25 & 16.4 & $1.00, \mathrm{~s}$ & 16.4 & $1.01, \mathrm{~s}$ & 16.4 & $1.01, \mathrm{~s}$ \\
\hline 26 & 17.7 & $0.97, \mathrm{~s}$ & 17.7 & $0.98, \mathrm{~s}$ & 17.7 & $0.98, \mathrm{~s}$ \\
\hline 27 & 27.3 & $1.40, \mathrm{~s}$ & 27.4 & $1.41, \mathrm{~s}$ & 27.4 & $1.40, \mathrm{~s}$ \\
\hline $28 \mathrm{a}$ & 65.8 & $3.64, \mathrm{~d}(12.0)$ & 65.8 & $3.65, \mathrm{~d}(12.0)$ & 65.9 & $3.65, \mathrm{~d}(12.1)$ \\
\hline $28 \mathrm{~b}$ & & 3.27 , overlap & & $3.29, \mathrm{~d}(12.0)$ & & $3.29, \mathrm{~d}(12.0)$ \\
\hline 29 & 32.6 & $0.93, \mathrm{~s}$ & 32.8 & $0.93, \mathrm{~s}$ & 32.8 & $0.93, \mathrm{~s}$ \\
\hline 30 & 29.1 & $1.05, \mathrm{~s}$ & 28.9 & $1.05, \mathrm{~s}$ & 28.9 & $1.05, \mathrm{~s}$ \\
\hline $1^{\prime}$ & 106.9 & $4.38, \mathrm{~d}(7.1)$ & 106.9 & $4.38, \mathrm{~d}(7.8)$ & 105.5 & $4.47, \mathrm{~d}(7.6)$ \\
\hline $2^{\prime}$ & 75.6 & 3.28 , overlap & 75.7 & 3.27 , overlap & 83.4 & 3.51 , overlap \\
\hline $3^{\prime}$ & 78.1 & 3.41 , overlap & 78.2 & 3.42 , overlap & 78.3 & 3.61 , overlap \\
\hline $4^{\prime}$ & 73.8 & 3.50 , overlap & 73.9 & 3.49 , overlap & 73.8 & 3.51 , overlap \\
\hline $5^{\prime}$ & 76.8 & 3.68 , overlap & 76.9 & 3.63 , overlap & 77.1 & 3.61 , overlap \\
\hline $6^{\prime}$ & $\mathrm{n} / \mathrm{d}$ & & $\mathrm{n} / \mathrm{d}$ & & $\mathrm{n} / \mathrm{d}$ & \\
\hline $1^{\prime \prime}$ & 102.8 & $4.38, \mathrm{~d}(7.1)$ & 103.1 & $4.49, \mathrm{~d}(7.5)$ & 103.1 & $4.49, \mathrm{~d}(7.6)$ \\
\hline $2^{\prime \prime}$ & 74.5 & 3.23 , overlap & 72.8 & $3.44, \mathrm{dd}(9.1,7.5)$ & 72.8 & 3.44 , overlap \\
\hline $3^{\prime \prime}$ & 77.0 & 3.41 , overlap & 75.9 & $5.09, \mathrm{t}(9.1)$ & 75.9 & $5.09, \mathrm{t}(9.1)$ \\
\hline $4^{\prime \prime}$ & 71.2 & 3.52 , overlap & 70.8 & $4.87, \operatorname{td}(9.6,5.5)$ & 70.8 & $4.87, \operatorname{td}(9.6,5.4)$ \\
\hline $5^{\prime \prime} \mathrm{ax}$ & 66.5 & 3.29, overlap & 63.6 & 3.46 , dd $(11.6,10.0)$ & 63.6 & 3.46 , overlap \\
\hline $5^{\prime \prime} \mathrm{eq}$ & & $3.95, \mathrm{dd}(11.6,4.9)$ & & $4.06, \mathrm{dd}(11.6,5.5)$ & & 4.06, dd $(11.6,5.4)$ \\
\hline OAc-3" & & & 172.2 & & 172.2 & \\
\hline & & & 21.0 & $2.08, \mathrm{~s}$ & 21.0 & $2.08, \mathrm{~s}$ \\
\hline OAc $-4^{\prime \prime}$ & & & 171.8 & & 171.8 & \\
\hline & & & 20.7 & $2.02, \mathrm{~s}$ & 20.7 & $2.02, \mathrm{~s}$ \\
\hline $1^{\prime \prime \prime}$ & & & & & 106.5 & $4.55, \mathrm{~d}(7.4)$ \\
\hline $2^{\prime \prime \prime}$ & & & & & 76.5 & $3.26, \mathrm{dd}(8.9,7.4)$ \\
\hline $3^{\prime \prime \prime}$ & & & & & 77.9 & 3.35, overlap \\
\hline $4^{\prime \prime \prime}$ & & & & & 71.4 & 3.49 , overlap \\
\hline $5^{\prime \prime \prime} \mathrm{ax}$ & & & & & 67.3 & 3.17 , overlap \\
\hline $5^{\prime \prime \prime} \mathrm{eq}$ & & & & & & 3.84, dd $(11.5,5.3)$ \\
\hline
\end{tabular}


Imbaloside $\mathrm{C}$ (3) was isolated as a colorless gum, with the molecular formula $\mathrm{C}_{50} \mathrm{H}_{78} \mathrm{O}_{20}$, by the deprotonated HRFABMS ion peak at $m / z 997.5002$ (calcd for $\mathrm{C}_{50} \mathrm{H}_{77} \mathrm{O}_{20}{ }^{-}$, 997.5014, error $=1.2 \mathrm{ppm}$ ). Inspection of the ${ }^{1} \mathrm{H}$ and ${ }^{13} \mathrm{C}$ NMR data of 3 proposed that these data closely resembled those of 2 , with a noticeable difference of the presence of one set of resonances attributable to a xylopyranose unit $\left[\delta_{\mathrm{H}} 4.55,3.84,3.49,3.35,3.26\right.$, and $3.17 ; \delta_{\mathrm{C}} 106.5,77.9,76.5,71.4$, and 67.3$]$ with a $\beta$-configuration suggested by the large coupling constant $\left(7.4 \mathrm{~Hz}\right.$ ) between $\mathrm{H}-1^{\prime \prime \prime}$ and $\mathrm{H}-2^{\prime \prime \prime}$ (Table 1$)$. The location of this additional xylopyranose unit was determined by the HMBC cross-peak of $\mathrm{H}-1^{\prime \prime \prime}\left(\delta_{\mathrm{H}} 4.55\right)$ to C-2' $\left(\delta_{C} 83.4\right)$ (Figure 2). Moreover, detailed inspection of the NOESY correlations verified that the relative configuration of $\mathbf{3}$ was all the same as those of $\mathbf{1}$ and $\mathbf{2}$. Thus, the structure of $\mathbf{3}$ was elucidated as 3-O-[ $\beta$-D-xylopyranosyl-( $1 \rightarrow 2)]-\beta$-D-glucuronyl-3 $\beta, 16 \alpha, 22 \beta, 28$-tetrahydroxyolean-12-ene-22-O(3,4-O-diacetyl)- $\beta$-D-xylopyranoside.

\subsection{Cytotoxicity Assessment}

The cytotoxicity was assessed based on the inhibitory effects of the compounds (1-3) on the growth of the four human tumor cell lines A549, SK-OV-3, SK-MEL-2, and BT549 using a sulforhodamine B (SRB) assay. As shown in Table 2, imbaloside B (2) displayed weak cytotoxicity against the BT549 cell line with an $\mathrm{IC}_{50}$ value of $26.4 \mu \mathrm{M}$, whereas it was inactive against the other cell lines $\left(\mathrm{IC}_{50}>30 \mu \mathrm{M}\right)$. Imbaloside C (3) showed mild cytotoxic activities against the A549 and BT549 cell lines with $\mathrm{IC}_{50}$ values of 29.8 and $29.2 \mu \mathrm{M}$, respectively. Cisplatin was used as a positive control with $\mathrm{IC}_{50}$ values of 0.9-2.0 $\mu \mathrm{M}$ against the four tumor cell lines (Table 2).

Table 2. Cytotoxicity of compounds 1-3 against four cultured human cancer cell lines in the sulforhodamine B (SRB) bioassay.

\begin{tabular}{ccccc}
\hline \multirow{2}{*}{ Compound } & \multicolumn{4}{c}{ IC $_{\mathbf{5 0}}(\boldsymbol{\mu M})^{\mathbf{1}}$} \\
\cline { 2 - 5 } & A549 & SK-OV-3 & SK-MEL-2 & BT549 \\
\hline $\mathbf{1}$ & $>30$ & $>30$ & $>30$ & $>30$ \\
$\mathbf{2}$ & $>30$ & $>30$ & $>30$ & 26.4 \\
$\mathbf{3}$ & 29.8 & $>30$ & $>30$ & 29.2 \\
Cisplatin $^{2}$ & 0.9 & 2.0 & 1.1 & 1.2 \\
\hline
\end{tabular}

${ }^{1} 50 \%$ inhibitory concentration; the concentration of a compound that caused a $50 \%$ inhibition in cell growth. ${ }^{2}$ Positive control substance.

\subsection{Anti-Neuroinflammatory Activity}

The potential anti-neuroinflammatory activity of the new compounds (1-3) was also evaluated by measuring the nitric oxide (NO) production levels in the LPS-stimulated murine microglia BV-2 cell line. The tested compounds (1-3) exerted moderate inhibition levels of NO production with $\mathrm{IC}_{50}$ values ranging from 33.8 to $41.0 \mu \mathrm{M}$ without significant cell toxicity. L-NMMA ( $\mathrm{IC}_{50} 21.3 \mu \mathrm{M}$ ) was used as a positive control (Table 3).

Table 3. Inhibitory effect of compounds $\mathbf{1}-\mathbf{3}$ on nitric oxide (NO) production in LPS-activated BV-2 cells.

\begin{tabular}{ccc}
\hline Compound & IC $_{\mathbf{5 0}}(\boldsymbol{\mu M})^{\mathbf{1}}$ & Cell viability (\%) \\
\hline $\mathbf{1}$ & 41.0 & $109.2 \pm 6.0$ \\
$\mathbf{2}$ & 33.8 & $97.5 \pm 2.1$ \\
$\mathbf{3}$ & 34.8 & $83.7 \pm 3.8$ \\
L-NMMA $^{3}$ & 21.3 & $120.1 \pm 11.7$
\end{tabular}

1 The $\mathrm{IC}_{50}$ value of each compound is defined as the concentration $(\mu \mathrm{M})$ that caused $50 \%$ inhibition of NO production in LPS-activated BV-2 cells. ${ }^{2}$ The cell viability following treatment with $20 \mu \mathrm{M}$ of each compound was determined using an MTT assay and is expressed as a percentage (\%). Data are expressed as the mean \pm SD of three independent experiments. ${ }^{3}$ Positive control substance. 
Many oleanane-type triterpenoids and their glycosides have shown potent cytotoxicity and anti-neuroinflammatory activity that are consistent with our current study [16,21-24]. This implied that the well-known oleanane-type triterpenoids are still good sources for future drug candidates to treat cancer or inflammation-related diseases.

\section{Materials and Methods}

\subsection{General Experimental Procedures}

Optical rotation data were recorded using a JASCO P-1020 polarimeter (JASCO, Easton, MD, USA). The NMR studies were accomplished employing a Bruker AVANCE III 700 NMR spectrometer (Bruker, Karlsruhe, Germany) and resultant spectra were processed using MestReNova (Mnova) (version 14.1.2-25024) with default weighting functions. HRFABMS data were acquired on a Waters SYNAPT G2 (Milford, MA, USA). The HPLC-DAD-MS data were measured using an Agilent 1260 Infinity HPLC system (Agilent, Santa Clara, CA, USA) with a Kinetex $\mathrm{C}_{18} 5 \mu \mathrm{m}$ column $(250 \mathrm{~mm}$ length $\times 4.6 \mathrm{~mm}$ i.d.; Phenomenex, Torrance, CA, USA). Purification was achieved using a semi-preparative HPLC system equipped with a Gilson 306 pump (Middleton, WI, USA), a Shodex refractive index detector (New York, NY, USA), and a Luna $\mathrm{C}_{18} 10 \mu \mathrm{m}$ column (250 mm length $\times 10 \mathrm{~mm}$ i.d.; Phenomenex, Torrance, CA, USA). Low-pressure liquid chromatography (LPLC) was performed with a LiChroprep Lobar-A Si 60 column (Merck, Darmstadt, Germany) and an FMI QSY-0 pump (Teledyne Isco, Lincoln, NE, USA). Open columns packed with silica gel 60 (70-230 and 230-400 mesh; Merck) or RP-C18 silica gel (230-400 mesh; Merck, Darmstadt, Germany) were implemented for crude fractionation and separation. Precoated silica gel F254 plates and RP-18 F254s plates (Merck) were utilized for thin-layer chromatography (TLC).

\subsection{Plant Material}

The air-dried white flowers of I. balsamina were collected in Asan, Korea, in August 2014, and the plant was identified by one of the authors (K.R.L.). A voucher specimen (SKKU-NPL 1406) was deposited in the herbarium of the School of Pharmacy, Sungkyunkwan University, Suwon, Korea.

\subsection{Extraction and Isolation}

The white flowers of I. balsamina $(3.0 \mathrm{~kg}$ ) were extracted with $80 \%$ aqueous $\mathrm{MeOH}$ under reflux and filtered. The filtrate was concentrated under a reduced pressure to obtain a $\mathrm{MeOH}$ extract $(730 \mathrm{~g})$. The crude extract was suspended in distilled $\mathrm{H}_{2} \mathrm{O}$ and successively partitioned with $n$-hexane, $\mathrm{CHCl}_{3}$, EtOAc, and $n$-butanol, yielding 62, 55, 50, and $86 \mathrm{~g}$ of the respective solvent residues. The EtOAc-soluble fraction $(20 \mathrm{~g})$ was separated over a silica gel column $\left(\mathrm{CHCl}_{3}-\mathrm{MeOH}-\mathrm{H}_{2} \mathrm{O}, 4: 1: 0.1\right)$ to yield eight fractions (A-H). Fraction $\mathrm{E}(1.5 \mathrm{~g})$ was chromatographed on an $\mathrm{RP}^{-} \mathrm{C}_{18}$ silica gel column (55\% aqueous $\mathrm{MeOH})$ to yield nine subfractions (E1-E9). Compounds $2(5 \mathrm{mg})$ and $3(3 \mathrm{mg})$ were obtained from subfraction E8 $(230 \mathrm{mg})$ using a Lobar-A Si 60 column $\left(\mathrm{CHCl}_{3}-\mathrm{MeOH}-\mathrm{H}_{2} \mathrm{O}, 4: 1: 0.1\right)$ followed by semi-preparative HPLC ( $30 \%$ aqueous MeCN). Fraction F (1.0 g) was applied to an RP-C 18 silica column ( $55 \%$ aqueous $\mathrm{MeOH})$ and further purified by semi-preparative HPLC ( $25 \%$ aqueous MeCN) to afford compound $\mathbf{1}(10 \mathrm{mg})$.

\subsubsection{Imbaloside A (1)}

Colorless gum; $[\alpha]_{\mathrm{D}}^{25}+11$ (c 0.1, MeOH); ${ }^{1} \mathrm{H}(700 \mathrm{MHz})$ and ${ }^{13} \mathrm{C}$ NMR $(175 \mathrm{MHz})$ data, see Table 1; HRFABMS (negative-ion mode) $\mathrm{m} / \mathrm{z} 781.4368[\mathrm{M}-\mathrm{H}]^{-}$(calcd for $\mathrm{C}_{41} \mathrm{H}_{65} \mathrm{O}_{14}{ }^{-}, 781.4380$, error $=1.5 \mathrm{ppm}$ ).

\subsubsection{Imbaloside B (2)}

Colorless gum; $[\alpha]_{\mathrm{D}}^{25}+15$ (c 0.1, MeOH); ${ }^{1} \mathrm{H}(700 \mathrm{MHz})$ and ${ }^{13} \mathrm{C}$ NMR $(175 \mathrm{MHz})$ data, see Table 1; HRFABMS (negative-ion mode) $\mathrm{m} / \mathrm{z} 865.4580[\mathrm{M}-\mathrm{H}]^{-}$(calcd for $\mathrm{C}_{45} \mathrm{H}_{69} \mathrm{O}_{16}{ }^{-}, 865.4591$, error $=1.3 \mathrm{ppm}$ ). 


\subsubsection{Imbaloside C (3)}

Colorless gum; $[\alpha]_{\mathrm{D}}^{25}+30(\mathrm{c} 0.2, \mathrm{MeOH}) ;{ }^{1} \mathrm{H}(700 \mathrm{MHz})$ and ${ }^{13} \mathrm{C}$ NMR $(175 \mathrm{MHz})$ data, see Table 1; HRFABMS (negative-ion mode) $\mathrm{m} / z$ 997.5002 [M - H] $]^{-}$(calcd for $\mathrm{C}_{50} \mathrm{H}_{77} \mathrm{O}_{20}{ }^{-}$, 997.5014, error $=1.2 \mathrm{ppm}$ ).

\subsection{Acid Hydrolysis of 1-3 and Sugar Analysis}

Compounds 1-3 (1 mg) were individually hydrolyzed with $1 \mathrm{~N} \mathrm{HCl}(1 \mathrm{~mL})$ under reflux for $2 \mathrm{~h}$. $\mathrm{CHCl}_{3}$ was used to extract organic layers from each reaction mixture. The monosaccharides acquired from $\mathrm{H}_{2} \mathrm{O}$-soluble phases were added to pyridine $(0.5 \mathrm{~mL})$ containing L-cysteine methyl ester hydrochloride $(0.5 \mathrm{mg})$ and the respective reaction mixtures were stirred at $60^{\circ} \mathrm{C}$ for $1 \mathrm{~h}$. Then, $o$-tolyl isothiocyanate $(0.1 \mathrm{~mL})$ was added and stirred at $60^{\circ} \mathrm{C}$ for another $1 \mathrm{~h}$. Each reaction mixture was analyzed without purification by LC-MS analysis $\left(0.7 \mathrm{~mL} / \mathrm{min} ; 25 \%\right.$ aqueous $\mathrm{CH}_{3} \mathrm{CN}$ with $0.1 \%$ formic acid for $30 \mathrm{~min}$ ). The authentic samples of D-xylopyranose, L-xylopyranose, and D-glucuronic acid were derivatized and analyzed by the same method as described above. Since standard L-glucuronic acid was not commercially available, we derivatized D-glucuronic acid with enantiomeric D-cysteine methyl ester hydrochloride to deduce the retention time of the L-glucuronic acid derivative. The hydrolysate derivatives of 1-3 were detected at $23.3 \mathrm{~min}$ for D-xylopyranose and $20.4 \mathrm{~min}$ for D-glucuronic acid in the LC-MS analysis, which corresponded with those of D-forms of authentic sugars (23.3 min for D-xylopyranose, $21.4 \mathrm{~min}$ for L-xylopyranose, $20.4 \mathrm{~min}$ for D-glucuronic acid, and $19.6 \mathrm{~min}$ for L-glucuronic acid).

\subsection{Cytotoxicity Assessment}

The cytotoxicity of the purified metabolites was tested against the A549 (non-small cell lung adenocarcinoma), SK-OV-3 (ovary malignant ascites), SK-MEL-2 (skin melanoma), and BT549 (invasive ductal carcinoma), utilizing the sulforhodamine B (SRB) colorimetric method [25]. Cisplatin ( $\geq 98 \%$; Sigma-Aldrich, St. Louis, MO, USA) served as a positive control.

\subsection{Assessment of NO Generation and Cell Viability}

The BV-2 cells, developed by Dr. V. Bocchini at the University of Perugia (Perugia, Italy), were used for this study [26,27]. The cells were seeded in a 96-well plate $(4 \times 104$ cells/well $)$ and incubated in the presence or absence of various doses of the tested compounds. Lipopolysaccharide (LPS) (100 ng/mL) was added to BV-2 cells and grown for $1 \mathrm{~d}$. The produced levels of nitrite $\left(\mathrm{NO}_{2}\right)$, a soluble oxidized product of $\mathrm{NO}$, were evaluated with $0.1 \% \mathrm{~N}-1$-napthylethylenediamine dihydrochloride and $1 \%$ sulfanilamide in $5 \%$ phosphoric acid, also known as the Griess reagent. The supernatant $(50 \mu \mathrm{L})$ was mixed with the Griess reagent $(50 \mu \mathrm{L})$. After $10 \mathrm{~min}$, the absorbance was gauged at $570 \mathrm{~nm}$. For a positive control, the reported nitric oxide synthase (NOS) inhibitor L-NMMA was employed. Graded sodium nitrite solution was utilized to determine nitrite concentrations. An MTT assay was used for the cell viability assay.

\section{Conclusions}

In this study, we described the characterization of three new oleanane-type triterpenoidal glycosides (1-3) using spectroscopic and spectrometric data analyses and chemical methods. It is the first to report oleanane-type triterpenoids from I. balsamina, whereas two other types of triterpenoids, baccharane [28-31] and ursane [32], were known from this plant. Although further studies are needed, the cytotoxicity and inhibitory potency on NO production of the isolated compounds (1-3) indicated that these compounds would be potential drug candidates.

Supplementary Materials: The following are available online at http://www.mdpi.com/2223-7747/9/9/1083/s1, NMR and HRMS data of 1-3.

Author Contributions: Investigation, T.H.L., W.S.S., L.S., S.U.C., and C.S.K.; Supervision, S.Y.K., S.U.C., and K.R.L.; Writing-original draft, T.H.L. and C.S.K.; Writing-review and editing, T.H.L. and C.S.K. All authors have read and agreed to the published version of the manuscript. 
Funding: This work was supported by the National Research Foundation (NRF) of Korea grant funded by the government of Korea (MSIT) (No. 2020R1F1A1073119).

Acknowledgments: We are thankful to the Korea Basic Science Institute (KBSI) for the measurements of mass spectra.

Conflicts of Interest: The authors declare no conflict of interest.

\section{References}

1. Imam, M.Z.; Nahar, N.; Akter, S.; Rana, M.S. Antinociceptive activity of methanol extract of flowers of Impatiens balsamina. J. Ethnopharmacol. 2012, 142, 804-810. [CrossRef]

2. Autore, G.; De Tommasi, N.; Aquino, R.; Garofalo, L.; Borrelli, F.; Tartaglia, D.; Mascolo, N. A new acetophenone derivative and inhibitory action of Muehlenbeckia volcanica on gastrointestinal transit in mice. Phytother. Res. 1996, 10, 202-206.

3. Ding, Z.-S.; Jiang, F.-S.; Chen, N.-P.; Lv, G.-Y.; Zhu, C.-G. Isolation and identification of an anti-tumor component from leaves of Impatiens balsamina. Molecules 2008, 13, 220-229. [CrossRef]

4. Oku, H.; Ishiguro, K. Cyclooxygenase-2 inhibitory 1, 4-naphthoquinones from Impatiens balsamina L. Biol. Pharm. Bull. 2002, 25, 658-660. [CrossRef]

5. Li, Q.; Guo, Z.; Wang, K.; Zhang, X.; Lou, Y.; Zhao, Y.-Q. Two new 1, 4-naphthoquinone derivatives from Impatiens balsamina L. flowers. Phytochem. Lett. 2015, 14, 8-11. [CrossRef]

6. Kim, C.S.; Subedi, L.; Kwon, O.W.; Park, H.B.; Kim, S.Y.; Choi, S.U.; Lee, K.R. Wasabisides A-E, lignan glycosides from the roots of Wasabia japonica. J. Nat. Prod. 2016, 79, 2652-2657. [CrossRef]

7. Kim, C.S.; Subedi, L.; Kim, S.Y.; Choi, S.U.; Kim, K.H.; Lee, K.R. Diterpenes from the trunk of Abies holophylla and their potential neuroprotective and anti-inflammatory activities. J. Nat. Prod. 2016, 79, 387-394. [CrossRef]

8. Kim, C.S.; Subedi, L.; Kim, S.Y.; Choi, S.U.; Kim, K.H.; Lee, K.R. Lignan glycosides from the twigs of Chaenomeles sinensis and their biological activities. J. Nat. Prod. 2015, 78, 1174-1178. [CrossRef]

9. Lee, T.H.; Khan, Z.; Kim, S.Y.; Lee, K.R. Thiohydantoin and hydantoin derivatives from the roots of Armoracia rusticana and their neurotrophic and anti-neuroinflammatory activities. J. Nat. Prod. 2019, 82, 3020-3024. [CrossRef]

10. Lee, T.H.; Khan, Z.; Subedi, L.; Kim, S.Y.; Lee, K.R. New bis-thioglycosyl-1, 1'-disulfides from Nasturtium officinale R. Br. and their anti-neuroinflammatory effect. Bioorgan. Chem. 2019, 86, 501-506. [CrossRef]

11. Suh, W.S.; Kwon, O.K.; Lee, T.H.; Subedi, L.; Kim, S.Y.; Lee, K.R. Secoiridoid glycosides from the twigs of Ligustrum obtusifolium possess anti-inflammatory and neuroprotective effects. Chem. Pharm. Bull. 2018, 66, 78-83. [CrossRef] [PubMed]

12. Kim, C.S.; Subedi, L.; Kim, S.Y.; Choi, S.U.; Choi, S.Z.; Son, M.W.; Kim, K.H.; Lee, K.R. Two new phenolic compounds from the white flower of Impatiens balsamina. Phytochem. Lett. 2015, 14, 215-220. [CrossRef]

13. Kim, C.S.; Bae, M.; Oh, J.; Subedi, L.; Suh, W.S.; Choi, S.Z.; Son, M.W.; Kim, S.Y.; Choi, S.U.; Oh, D.C.; et al. Anti-neurodegenerative biflavonoid glycosides from Impatiens balsamina. J. Nat. Prod. 2017, 80, 471-478. [CrossRef] [PubMed]

14. Kim, C.S.; Subedi, L.; Oh, J.; Kim, S.Y.; Choi, S.U.; Lee, K.R. Bioactive triterpenoids from the twigs of Chaenomeles sinensis. J. Nat. Prod. 2017, 80, 1134-1140. [CrossRef] [PubMed]

15. Kim, K.H.; Lee, I.K.; Choi, S.U.; Lee, J.H.; Moon, E.; Kim, S.Y.; Lee, K.R. New triterpenoids from the tubers of Corydalis ternata: Structural elucidation and bioactivity evaluation. Planta Med. 2011, 77, 1555-1558. [CrossRef]

16. Lee, I.K.; Choi, S.U.; Lee, K.R. Triterpene saponins from Pleurospermum kamtschaticum and their biological activity. Chem. Pharm. Bull. 2012, 60, 1011-1018. [CrossRef]

17. Carrillo, M.R.; Mitaine-Offer, A.-C.; Miyamoto, T.; Tanaka, C.; Pouységu, L.; Quideau, S.; Rojas, L.B.; Porcar, C.R.; Lacaille-Dubois, M.-A. Oleanane-type glycosides from Pittosporum tenuifolium "variegatum" and P. tenuifolium "gold star". Phytochemistry 2017, 140, 166-173. [CrossRef]

18. Mroczek, A.; Kapusta, I.; Janda, B.; Janiszowska, W. Triterpene saponin content in the roots of red beet (Beta vulgaris L.) cultivars. J. Agric. Food Chem. 2012, 60, 12397-12402. [CrossRef]

19. Ragasa, C.Y.; Espineli, D.L.; Shen, C.-C. New triterpenes from Barringtonia asiatica. Chem. Pharm. Bull. 2011, 59, 778-782. [CrossRef] 
20. Tanaka, T.; Nakashima, T.; Ueda, T.; Tomii, K.; Kouno, I. Facile discrimination of aldose enantiomers by reversed-phase HPLC. Chem. Pharm. Bull. 2007, 55, 899-901. [CrossRef]

21. Kim, K.H.; Choi, S.U.; Lee, K.R. Cytotoxic triterpenoids from Berberis koreana. Planta Med. 2012, 78, 86-89. [CrossRef] [PubMed]

22. Woo, K.W.; Cha, J.M.; Choi, S.U.; Lee, K.R. A new triterpene glycoside from the stems of Lagerstroemia indica. Arch. Pharm. Res. 2016, 39, 631-635. [CrossRef] [PubMed]

23. Suh, W.S.; Park, K.J.; Kim, D.H.; Subedi, L.; Kim, S.Y.; Choi, S.U.; Lee, K.R. A biphenyl derivative from the twigs of Chaenomeles speciosa. Bioorgan. Chem. 2017, 72, 156-160. [CrossRef] [PubMed]

24. Park, K.J.; Subedi, L.; Kim, S.Y.; Choi, S.U.; Lee, K.R. Bioactive triterpenoids from twigs of Betula schmidtii. Bioorgan. Chem. 2018, 77, 527-533. [CrossRef] [PubMed]

25. Skehan, P.; Storeng, R.; Scudiero, D.; Monks, A.; McMahon, J.; Vistica, D.; Warren, J.T.; Bokesch, H.; Kenney, S.; Boyd, M.R. New colorimetric cytotoxicity assay for anticancer-drug screening. J. Natl. Cancer Inst. 1990, 82, 1107-1112. [CrossRef]

26. Blasi, E.; Barluzzi, R.; Bocchini, V.; Mazzolla, R.; Bistoni, F. Immortalization of murine microglial cells by a v-raf/v-myc carrying retrovirus. J. Neuroimmunol. 1990, 27, 229-237. [CrossRef]

27. Choi, Y.; Lee, M.; Lim, S.; Sung, S.; Kim, Y. Inhibition of inducible NO synthase, cyclooxygenase-2 and interleukin-1 $\beta$ by torilin is mediated by mitogen-activated protein kinases in microglial BV2 cells. Br. J. Pharmacol. 2009, 156, 933-940. [CrossRef]

28. Shoji, N.; Umeyama, A.; Taira, Z.; Takemoto, T.; Nomoto, K.; Nizukawa, K.; Ohizumi, Y. Chemical structure of hosenkol-A, the first example of the natural baccharane triterpenoid of the missing intermediate to shionane and lupane. J. Chem. Soc. Chem. Commun. 1983, 871-873. [CrossRef]

29. Shoji, N.; Umeyama, A.; Saitou, N.; Yoshikawa, K.; Kan, Y.; Arihara, S. Hosenkosides A, B, C, D and E, novel baccharane glycosides from the seeds of Impatiens balsamina. Tetrahedron 1994, 50, 4973-4986. [CrossRef]

30. Shoji, N.; Umeyama, A.; Saitou, N.; Yoshikawa, K.; Nagai, M.; Arihara, S. Hosenkosides F, G, H, I, J and K, novel baccharane glycosides from the seeds of Impatiens balsamina. Chem. Pharm. Bull. 1994, 42, 1422-1426. [CrossRef]

31. Shoji, N.; Umeyama, A.; Yoshikawa, K.; Nagai, M.; Arihara, S. Baccharane glycosides from seeds of Impatiens balsamina. Phytochemistry 1994, 37, 1437-1441. [CrossRef]

32. Lei, J.; Qian, S.; Jiang, J. A new ursane caffeoyl ester from the seeds of Impatiens balsamina L. J. China Pharmceutical Univ. 2010, 41, 118-119. 